\title{
History Of Hydraulics and Fluid Mechanics At Colorado State University
}

\author{
Pierre Y. Julien ${ }^{1}$ and Robert N. Meroney ${ }^{2}$ \\ Civil Engineering Department, Colorado State University
}

\begin{abstract}
The development of hydraulics and fluid mechanics at Colorado State University is reviewed in reference to those who pioneered the analysis of hydraulic and wind engineering. The article will first cover the Aarly developments@with Elwood Meade, Charles Lory, Ralph Parshall and Emory Lane during the Colorado A\&M period. The name change to Colorado State University initiated considerable expansion through fruitful collaboration with the USGS and the USBR. The Axpansion years@featured the contributions of Maury Albertson, Hunter Rouse, Jack Cermak and Everett Richardson with direct administrative support from Lionel Baldwin, Daryl Simons and Ray Chamberlain. The more recent Amature period@saw broadening of the programs and expansion into environmental engineering. The emphasis of the article will be on the historical contribution of CSU to hydraulics and fluid mechanics. Some of the key scientific achievements will be reviewed. There will be a brief documentation of the interaction between faculty activities, academic programs and research facilities that led to rapid growth and development. The success and visibility of the programs also hinged on several other factors including significant contributions at the international level through projects in Pakistan (Tarbela Dam) and Egypt.
\end{abstract}

In 1862, the United States Congress passed the Morrill Act granting land to each state in the amount of 30,000 acres for every senator and representative, thus Colorado received 90,000 acres. The receipts from the sale of this land were to form a perpetual fund with interest to support "at least one college to teach agriculture and the mechanic arts. Although the 1862 Act gave the state a grant of federal land for a college, it was not necessary to locate the college on the grant. In 1870 Governor Edward M. McCook signed the Territorial Bill establishing the Agricultural College of Colorado at Fort Collins. In November of 1874 the first small building, called the "claim shanty," was completed. According to tradition, it was built in eight days in order to prevent the site of the college from being moved to some other town. It is known that both Greeley and Boulder were circulating petitions to get the college away from Fort Collins.

Colorado was admitted to statehood in 1876, and the first State Legislature established the State Board of Agriculture in 1877, governing body for the agricultural college. The Agricultural College of Colorado was to be governed by a Board of Agriculture of eight men, at least four of whom had to be

\footnotetext{
${ }^{1}$ Borland Professor of Hydraulics, Department of Civil Engineering, Colorado State University, Fort Collins, CO 80523-1320, 970-491-8450, pierre@engr.colostate.edu

${ }^{2}$ Director Emeritus of the Fluid Mechanics and Wind Engineering Program, Department of Civil Engineering, Colorado State University, Fort Collins, CO 80523, 970-491-8574, meroney@engr.colostate.edu
} 
practicing farmers. It was about this time that a member of the legislature stated he felt money spent for an agricultural college would be money thrown away, as Colorado would never be an agricultural state - it was only fit for cow pasture and mining. Not until 1878 were funds for the College actually appropriated. Ground was broken for the "college building" later known as Old Main about June 20, 1878, and the formal laying of the cornerstone was on July 27 at public ceremonies.

\section{The Pioneers}

The staff member who was to play the initial role in hydraulics was originally employed by the College in 1882 as an instructor in mathematics. This was Elwood Mead (1858-1936) who had studied civil engineering at Purdue and Iowa State. In 1883, Mead received approval of his proposal to teach a two-term senior course on irrigation, one term to be "devoted to the pressure and flow of water, and methods of determining the same;" and the other "to the survey and construction of canals and reservoirs." That year Mead also became assistant state engineer doing practical field work in irrigation. It is said that the State Board of Agriculture was interested in Mead because he would accept a position without the promise of a professorship the second year. In view of the shortage of funds, this could well be true. Mead evidently believed that the opportunity to serve in a needful area was more to be desired than rank. And immediately he was thrown almost literally and physically into the complicated problems of irrigation as they were developing in the Cache la Poudre Valley.

Irrigation was neither a new thing in the world nor even unknown in Colorado when the farmers in Larimer County unknowingly began to develop a laboratory that was to become world famous and where faculty men from the College would work long hours. If any place ever needed irrigation, it was this area. When men fought and threatened to kill in order to obtain water for irrigation, a way of measuring water so that each man might receive his fair share was an urgent need. Serving as assistant to the State Engineer, E.S. Nettleton, Mead struggled with problems of measuring water, building ditches to get water onto the land, and storage of water. Few laws were in existence, even in the United States, to control the use of water for irrigation. And before laws could be passed, a concept of water as property had to be accepted. How was a man to acquire a right to water and to how much water? How was running water to be measured? These were questions of great social and economic importance.

In 1886, Mead became the first professor of irrigation engineering in the United States. At the College, Mead taught courses in "measurement and flow of water for irrigation." This was followed by work in hydraulics, canals, and dams. One of their first projects as a class was not how to get water onto the land, but how to get it off. Working through head-high cattails, they surveyed and drained the swampy streams that crossed the campus.

It is said that President Ingersoll and the State Board of Agriculture 
created the professor position in an attempt to hold Mead on campus. At any rate, he left in 1888 to go to Wyoming where he wrote the irrigation code for that territory. As Wyoming's first State Engineer, Elwood Mead framed a revolutionary code of water law for arid and semiarid regions which was written into Wyoming's constitution and which became a model for irrigation laws adopted not only by four-fifths of the western states but also Canada, Australia, South Africa, and New Zealand. This new water law rejected the old English common-law principle of riparian rights as inappropriate for arid regions and instead declared all water, surface and underground, to be state property, thus giving them the same status as minerals and land and thereby ending legal conflicts between those who owned the land through which the water flowed and those who wished to use the water.

He was subsequently employed by the U.S. Department of Agriculture in Washington in 1899, the Australian Water Supply Commission, the University of California, and finally the U.S. Bureau of Reclamation in 1923, with which he served a dozen years as commissioner. The Board's findings were influential in the writing of the Reclamation Act of 1924. No doubt the caliber of the work Dr. Mead did on this board was one reason for his being appointed, also in 1924, as Chief of the Bureau of Reclamation, in which capacity he served for 12 years, until his death in 1936. F.D.Roosevelt said of Elwood Mead: "He was a builder with vision."

Mead's work as State Engineer had made him familiar with the terrain of northern Colorado and Wyoming. He and a young assistant had surveyed for the first time much of Yellowstone, traveling by buckboard. He knew "Buffalo Bill" Cody and explored with him in 1888 some of Wyoming's wild rivers. As commissioner of Reclamation he toured the West every year; indeed, he was out West planning for a new project only a few weeks before his death. Today, the lake above Hoover Dam now bears his name.

Engineering grew more rapidly than agriculture because of the very urgent demand for engineers in irrigation. Also, engineering as a profession had long been standardized while agriculture had not. The American Society of Civil Engineers had been founded in 1852. Engineering had a body of accumulated and tested principles it could make use of; but agriculture did not have this background - not nationally or in the state. A common attitude was "if my boy wants to be an engineer, I'll send him to college; but if he wants to be a farmer, I can teach him all he needs to know." About the turn of the century a controversy arose in Colorado concerning the emphasis of engineering over agriculture at the Agricultural College. One editorial writer pointed out that one student trained in irrigation engineering at the college was worth more to the state of Colorado than all the institution had cost.

By 1903 the school had grown to an enrollment of 448. Included in the graduating class of 1904 in Civil and Irrigation Engineering (C\&IE) was Ralph L. Parshall. Had the college kept a guest book during the early 1900's, many famous names would have been recorded. In August 1904, a commissioner and a prince from Ceylon, and a representative from Egypt 
came to the college to learn of Colorado agriculture and irrigation. Then about the time the new C\&IE building was first occupied, an expert sent by the Chilean government to study methods of irrigation and instruction in irrigation engineering in America, Egypt, Europe, and India reported that there was only one other institution in the world that had equipment for teaching and investigation in irrigation engineering equal to that of Colorado Agricultural College (CAC).

In 1910, the U.S. Department of Agriculture stationed Victor M. Cone (1883-1970) at Fort Collins to take charge of U.S. Irrigation Investigations, Bureau of Public Roads. This agency (forerunner of the Agricultural Research Service) in cooperation with the Colorado Agricultural Experiment Station was instrumental in building the new hydraulics laboratory of the C\&IE department, and in 1912 Cone and Parshall were involved in its design. The next year Parshall was promoted to assistant professor, but then he resigned from the college to accept a position with the USDA - remaining in residence, however, in the C\&IE building. He was replaced on the college staff by Oliver P. Pennock (1879-1968), a rather reserved 1902 graduate who 40 years later was to head the department. In 1914, Carl H. Rohwer (18901958) of Nebraska and Cornell was transferred to Fort Collins by the USDA, whereafter Cone, Parshall, and Rohwer proceeded to make the region - and vicariously the College - well recognized for irrigation research.

In 1920, a search was made by Parshall and Rohwer for an outdoor laboratory site, not too far from the city and with an ample supply of water. The waste gate on Jackson Ditch, leading from a branch of the Cache La Poudre River near Bellevue, northwest of Fort Collins, was found to meet their requirements, and a concrete channel 7x14x75 feet, tapering over another 50 feet to an outlet width of 25 feet, was connected to the gate. The latter permitted some adjustment to the flow, and a 15-foot weir was used for discharge measurement. It was in this channel that Parshall developed his adaptation of the Venturi flume for discharge measurement. Patented about 1925, it became widely known under his name and used around the world. Two of the advantages of the Parshall flume are: (1) it will not become filled with silt, and (2) it is accurate, even on a relatively flat land where velocity of water downstream is low. Successful operation depends mainly on selection of correct sizes and proper setting. It must be built according to exact dimensions specified, depending on size of throat required, and throat size depending on discharge. Parshall is only slightly lesser known for a series of sand traps he developed which are designed to keep irrigation canals free from sand.

\section{Growth On Campus}

In 1919, President Lory reported to the State Board of Agriculture that the college was out of debt. Between 1920 and 1930, he reported eleven buildings added to the campus. Local chapters of fraternities and sororities were beginning to become nationally affiliated around 1915. From the time the first dormitory was remodeled for civil engineering, there were no more 
dormitories on campus until the construction of Rockwell Hall about 1939. In 1919, Lory recommended that the College resume research into the possibility of diverting western slope snowmelt through the Continental Divide and onto the eastern plains. The drought and depression of the 1930's took their toll on the State but Lory was instrumental in organizing support and lobbying Reclamation commissioner Mead for backing. With the help of Parshall, among others, Lory then acquired a grant for the College from the Works Project Administration to conduct a feasibility study. By 1938, the construction of the $\$ 160$ million Colorado-Big-Thompson River Project was underway.

In August 1930, the Bureau of Reclamation sent a dozen engineers, technicians, and shop people from Denver to Fort Collins to work in the laboratory which had been designed by Cone and Parshall for the USDA. The Bureau program began with a study of proposed shaft spillways for Hoover Dam; as a result of these tests, a change was made from the shaft to the sidechannel type of structure. Thereafter, many other studies were undertaken, in particular for the Bureau's Grand Coulee and Imperial Dams and for the Tennessee Valley Authority's Wheeler and Norris Dams.

Emory W. Lane (1891-1963), who had studied at Purdue and Cornell and then seen considerable experience both in the States and in China, was administrative head of the Fort Collins operation. This involved two shifts during the Hoover spillway tests, under Charles W. Thomas (1906-1978) and James W. Ball (1905 -...), both Coloradoans educated at Fort Collins. Lane later went back to Denver, turning the Fort Collins work over to Jacob E. Warnock (1903-1949), with degrees from Purdue and Colorado. Upon Warnock's move to Denver, Ball was left in charge. By 1936, the laboratory had undergone a fourfold expansion, but for political and financial reasons the Bureau brought its work there to a close only two years later and withdrew to its Denver quarters in the New Customhouse. On his retirement from the Bureau of Reclamation in 1953, Emory Lane received a temporary appointment at Fort Collins, which he held until illness forced cessation of his activities in 1957; by then he was well along the road toward formulation of a general philosophy of sediment transport.

The name of the Colorado Agricultural College was changed in 1935 to Colorado State College of Agriculture and Mechanic Arts (only to change again to Colorado Agricultural and Mechanical College in 1944). Three years thereafter (1938) Pennock was replaced as Department Head and Dean by Nephi A. Christensen (1903-...), a native of Utah who had just obtained a Caltech doctorate under Theodor von Karman and Robert T. Knapp. Christensen's first accomplishment was to gain accreditation (previously refused) of his three engineering departments by the Engineers Council for Professional Development. One of his former colleagues at Caltech was the Toledoan Hunter Rouse (1906-...), who had just become a professor at the State University of Iowa when he was invited by Christensen to give a 1940 summer class at Fort Collins in the mechanics of fluids. This attracted some two dozen graduate students (among them J.C. Stevens, later president of the 
ASCE, and C.P. Better, sediment specialist of the Bureau of Reclamation), thus becoming the first of a continuing series of summer courses and conferences.

As the United States became involved in World War II, some college laboratories undertook war-related research. Christensen played an important part in the development of rocketry at the Army's Aberdeen Proving Grounds, taking with him a number of the College staff - in particular Dwight Gunder (1905-1964), a professor of engineering mathematics. At the same time, one who was to take a leading role in later developments at CSU, Maurice L. Albertson (1918-...) with degrees from Iowa State College and the State University of Iowa, was called back from TVA to the Iowa Institute of Hydraulic Research for war work under Rouse. This involved air-r tunnel tests on fog dispersal, turbulence, and jet diffusion, in the course of which he completed a doctoral dissertation on boundary-layer evaporation. Since he had long hoped to take part in the irrigation research at Colorado State, between Rouse and Christensen a position for him there was arranged in 1947.

At the time, Rouse opposed Albertson's move to CSU and warned him that if he'd move to CSU, nobody would ever hear of him again! Ironically, Rouse moved to Sun City, Arizona, and began teaching the summer course "Intermediate Fluid Mechanics" at CSU in 1976. Reminiscing Rouse's teaching, it quickly became clear that student involvement was insufficient for the study of fluid mechanics and that a full commitment was required of the students. As Daryl Simons aptly clarified the difference between involvement and commitment, if you have eggs and bacon for breakfast, the chicken was involved but the pig was committed. Hunter Rouse's summer teaching included a weekly classroom oral quiz where students were asked to answer various fluid mechanics questions in front of the class. After a student's answer, Rouse paused and said: "I have been teaching Fluid Mechanics for 50 years and this is the worst answer I ever heard". It is with pride that students were wearing "I survived Hunter Rouse" T-shirts in Fort Collins. He then retired in 1986.

Albertson contributed to the entrepreneurial spirit and served as catalyst for unprecedented research at the College. At the same time that engineering was beginning to build its graduate programs, it also embarked on its international programs in the 1950's, thus establishing one of the hallmark characteristics of the modern program. The cold war battle for the loyalties of third world countries centered the efforts on President Truman's Point IV program designed to aid the economic development of these regions. As part of this program, Colorado A\&M became involved in a faculty exchange program with its sister school, the University of Peshawar in Pakistan. Four years later, the State Department approached Maury Albertson with a request for a feasibility study for a proposed graduate engineering school in Southeast Asia. With members of the Southeast Asia Treaty Organization SEATO seeking the region's economic and social development, the SEATO Graduate School of Engineering opened in the Fall on 1959 with Maury Albertson as campus coordinator. In 1967, the college turned into the Asian Institute of 
Technology. During the decade 1950-1960, most of the research activity in engineering in Fort Collins was within the Civil Engineering Department. Research reached a volume of approximately $\$ 160,000$ in 1955-56 and $\$ 277,000$ in 1956-57. Contracts and grants provided most of the dollar volume of research which exceeded \$600,000 in 1961.

\section{Growth As Colorado State University}

College enrollment reached 1000 in 1924; 2000 in 1939, 6000 in 1960 and 16,000 in 1969. In 1935, due to the initiative of students and their continued agitations, the college became known as Colorado State College of Agriculture and Mechanic Arts. In 1944, the name was changed to Colorado Agricultural and Mechanical College. The year 1957 saw the change in the institution's name to Colorado State University. At this time, the academic divisions became colleges. T.H. Evans was Dean of the College of Engineering and D.F. Peterson was Head of the Civil Engineering Department. In 1958, M.E. Bender succeeded Peterson as Head of the Civil Engineering Department.

In 1957 has been a memorable year; the U.S. Geological Survey stationed Daryl B. Simons $(1918-\ldots)$ at Fort Collins to lead the growing research program on river mechanics and sediment transport with Everett $\mathrm{V}$. Richardson (1924-...). Simons not only supervised the USGS program but also completed work toward CSU's second engineering doctorate and then taught courses in civil engineering. His primary contribution was certainly on the analysis bedforms and resistance to flow in alluvial channels. He retired from CSU in 1983 and his expertise in sedimentation and river engineering has been sought after the world over. The same year, A.R. Chamberlain, professor of civil engineering, was made chief of the Civil Engineering Section. This was a position created to administer the burgeoning research section of Civil Engineering. The arrival in 1957 of Vujica Yevjevich

(1913-...) from the former Yugoslavia fostered rapid growth in Hydrology.

When Chamberlain became vice president for administration in 1960, he left his position as chief of the research section. This position remained vacant until 1963. At this time, Bender left as head of the department to become Chief of the U.S. party and Dean of the Southeast Asia Treaty Organization (SEATO) Graduate School of Engineering in Bangkok, Thailand. J.W.M. Fead became acting head of the Civil Engineering Department and D.B. Simons became acting head of the research section. Lionel Baldwin (1932-...) came to the campus in 1961, after experience with NACA-NASA; a chemical engineer, his specialty was fluid turbulence. William W. Sayre (1927-...) of New York and Princeton, initially a graduate student, became a member of the USGS staff in 1962, moving to Iowa in 1968 after receiving the doctorate; his particular interest was the mechanics of diffusion. Hsieh-Wen Shen (1931...), a native of China who, after study at Michigan, had taken the doctorate in sediment transport under H.A. Einstein at Berkeley (and was to become an ASCE Freeman Scholar the following 
year), arrived at Fort Collins in 1964. H.W. Shen's led numerous NSF projects in the field of sedimentation and river mechanics before returning to Berkeley in 1985. In 1965, Fead became Head of the Department and Simons became the Associate Dean for Research for the College of Engineering. This, of course, called for some reorganization of duties and responsibilities. Lionel Baldwin was appointed Dean of Engineering in 1965; and in 1969 Ray Chamberlain - for several years Vice President - assumed the post of President as the University was preparing to celebrate its centennial year.

In most respects the college of Engineering was well prepared to meet the demands of the boom years. Faculty expanded to more than 100 by the early 1970 's while funded research skyrocketed from just under $\$ 500,000$ to $\$ 5,000,000$. With the state supplying as little as half of the funds needed to for instruction in some departments, it became incumbent upon faculty to prove the axiom that an engineer can do as much with one dollar as others with two. This reliance on soft money was not for the faint of heart. As Civil Engineering Department Head J.W.N. "Bill" Fead explained: "faculty had a lot of freedom in the way they operated and a lot of pressure to bring their own salary. But they were the type of people who wanted control of their own projects and who were willing to put up with the hassles of the entrepreneurship requirement to have that kind of working environment."

\section{Growth At The Engineering Research Center}

A new Engineering Research Center was built in 1962 at a cost of $\$ 1.80$ million joining three wings together to provide 69,000 square feet of space for offices, conference rooms, small laboratories and electronics shops, printing, drafting, and photographic quarters, two lecture rooms, and a cafeteria. Directly south of the main wings and connected to them are two large laboratories each roughly $120 \times 280$ feet in plan.

\subsection{The Hydraulics Laboratory}

The permanent features of the Hydraulic Laboratory are a series of interconnected sumps 8 feet in depth and 5400 square feet in surface area; 14 pumps ranging in capacity from 250 gallons per minute at 50-foot head to 23,000 gallons per minute at 19-foot head; a power-tilting flume 4x8x200 feet with a discharge capacity of 100 cubic feet per second; a 20x100 foot riverbasin flume for meander, erosion, and control-structure studies; a large localscour flume; three other tilting flumes; and ample space for temporary models.

A 100-acre outdoor laboratory adjoins the building, making possible largescale model and full-scale prototype studies. A concrete flume 8x20x180 feet with a recessed section 10 feet deep provides a facility for large-scale tests. A 3-foot-diameter variable-slope pipe 825 feet long is also available. A hydromachinery facility is housed in a 70x192-foot prestressed-concrete building. The concrete floor slab was made 3 feet thick to eliminate vibration during testing. Water for both the indoor and outdoor laboratories comes from the U.S. Bureau of Reclamation's Horsetooth Reservoir just uphill to the west of 
the Research Center.

A maximum head and discharge on the order of 200 feet and 300 cubic feet per second are available. Modifications are currently underway that will increase the maximum available discharge to 500 cubic feet per second. In addition, large stationary and movable pumps are used to recirculate water from sumps and to increase the operating head.

With such facilities and staff - not to mention the considerable support of various agencies - recirculating and tilting flumes and additional structures came into being, and graduate enrollment steadily rose. As of September 1979 the staff of the combined hydraulics, fluid mechanics, and hydrology sections of the Civil Engineering Department has grown to a total membership of 125. Of these, 33 are of faculty rank, i.e., assistant professor or above, and 92 are graduate assistants. The hydraulics section is largest, with 69 members, and fluid mechanics next with 36 . About $55 \%$ of all graduate students in the Department are employed part-time, with an annual turnover of some $40-50 \%$.

\subsection{Fluid Mechanics and Wind Engineering}

The beginning of the Fluid Dynamics and Diffusion Laboratory (FDDL) [currently called the Wind Engineering and Fluids Laboratory, WEFL] was in 1949 when the first wind tunnel was designed and largely build by J.E. Cermak, who was at that time an instructor in the civil engineering department. The wind tunnel was located in the old Industrial Research Building, now called the General Services Building. Cermak and Albertson, at that time an associate professor in the civil engineering department, worked on the first research contract for the FDDL which was a grant from the Office of Naval Research, 1949-54, for a study on evaporation.

In 1955 the Army Air Force granted funds for a Meteorological Wind Tunnel, and this became operational alongside the first tunnel in the new Engineering Research Center in 1963. The Meteorological Wind Tunnel became the first wind engineering facility in the world to include a long test section in which a simulated atmospheric boundary layer grew naturally, and in which heated/cooled boundaries and thermal controls permitted simulation of day time convection and night time inversion conditions.

The Wind Engineering and Fluid Mechanics Program at Colorado State University under the direction of Dr. Jack E. Cermak grew substantially during the late 1960s, 70s and 80s until the program included some 12 faculty and research scientists and their graduate students. A third large facility, the Environmental Wind Tunnel was added with a test section 57 feet long and a $12 \times 8 \mathrm{ft}$ cross section to investigate wind effects over large terrain areas. During this time, Wind Engineering became a recognized engineering discipline, and in 1989 the National Society of Professional Engineers declared the CSU Wind Engineering and Fluids Laboratory one of the five major engineering accomplishments of the decade. 
Several facilities for specialized research augment the larger test facilities, including a Separated-Flow Facility which has a working section 2 feet-wide with flexible floor that can be adjusted over a length of 10 feet to provide a wide range of pressure variation in the flow direction. Aerosol dispersion can be studied in an Aerosol Test Facility with a 2x2-foot test section 15 feet long capable of producing air speeds up to 116 miles per hour and equipped with a remote-sensing laser-powered particle spectrometer. Studies of large-scale turbulence are made in a Gust Tunnel with a 3x3-foot test section equipped with two banks of airfoils whose pitch may be varied randomly by an electromechanical servo-system.

During the early 1960s models of the New York World Trade Center were examined in the Meteorological Wind Tunnel. Based on these measurements the original locations of the twin towers were reoriented, and a passive damping system was designed and installed in the towers to mitigate tower sway. Other early wind flow and loading studies included evaluations of wind effects at the Candlestick Ball Park, San Francisco, and the Oakland-Alameda County Coliseum. After the famous cladding failures that occurred in 1972 during the construction of the John Hancock building in Boston, Massachusetts, architect and design firms requested preventive model studies from CSU engineers, which resulted in many hundreds of model skyscraper studies in the CSU facilities during the 1970s and 1980s. In the late 1980s a model of the world's tallest building, the Chicago Sears Tower, was evaluated for wind effects to mitigate existing problems with glass and cladding damage.

In 1987, Robert N. Meroney, graduate of the University of California, Berkeley, led the program and emphasized research in areas of atmospheric transport of dense and buoyant gases, wind energy conversion and wind turbine siting, and computational fluid mechanics. He joined with Kishor Mehta of Texas Tech University and the two schools obtained the first multiyear US National Science Foundation Cooperative Program Grant. The grant focused on Wind Engineering and lasted from 1987 through 2001. This research program was directed to evaluate the hazards of extreme winds acting on low-rise buildings such as homes, churches, schools and shopping centers. The work resulted in a major revamping of the US National Wind Loading Design Codes, new specifications for extreme wind hazards for the continental United States, the creation of a major data base of field and laboratory wind load data, the incorporation of wind hazards into building insurability criteria, and a new understanding of the role of corner vortices in the wind loading of civil engineering structures. Other research associated with this grant included simulation of infiltration and exfiltration across building envelopes, and wind blown debris. Other contributors to the program include Jon A. Peterka, Willy Z Sadeh, and Virgil A. Sandborn.

\section{Recent Years}

In the 1980's, E.V. Richardson has been leading the development of water resources at the International level and particularly in Egypt where CSU 
trained a generation of scientists and engineers with expertise in hydraulics and water resources. This successful program brought in about $\$ 60,000,000$ to CSU from 1977-89. Richardson remains very active in the field of bridge hydraulics and led numerous projects on pier scour and stream stability with the Federal Highway Administration since retirement in 1989. Daniel K. Sunada took over the Egypt Water Research Center program that brought an additional $\$ 20,000,000$ to CSU from 1989-93.

In the past two decades, the Hydraulics Laboratory has seen the construction and analysis of numerous large-scale physical models including several dams, spillways, energy dissipators, river models, analyses of resistance to flow, sediment transport, riprap and block stability, filter design, river morphology, local scour, bridge hydraulics, environmental hydraulics, surface runoff and sheet erosion, infiltration and contaminant transport, mudflow and debris flows, dam break, reservoir sedimentation, etc. Primary contributors to the Hydraulics Laboratory at the Engineering Research Center in the past several decades include Everett V. Richardson, Susumu Karaki, James F. Ruff, Stanley A. Schumm, Hsieh Wen Shen, Steven R. Abt, Pierre Y. Julien, Carl F. Nordin, Albert Molinas, Chester W. Watson, and many others. Hydraulics faculty members remembered for developing effective teaching methods include Herman J. Koloseus, Morris M. Skinner and Johannes Gessler.

In hydrology, Yevjevich's most important contribution may have been the foundation of the Water Resources Publications, which served as a platform to display all the cumulated knowledge at CSU in the field of "water resources". The books published at CSU in the 70's certainly constitute a landmark in our field. The books encompassed the fields of river mechanics, sediment transport, stochastic processes, hydrologic modeling, surface runoff, unsteady flow, groundwater and water resources planning and management, etc. Many faculty made significant contributions to the Hydrology program including Hubert Morel-Seytoux in the field of surface hydrology and infiltration, Hsieh-Wen Shen in the field of stochastic sediment transport and river mechanics, Jose D. Salas in the field of stochastic hydrology, David Woolhiser in the area of surface runoff, Roger E. Smith in the field of infiltration, and Jorge A. Ramirez in large scale hydrology. Some of the hydrology work overlapped other contributions in the groundwater program by Daniel K. Sunada and James W. Warner. Although in a separate Water Resources Planning and Management program, other contributors to a broader hydrology include Neil S. Grigg and John W. Labadie, Darrell G. Fontane, Warren A. Hall and Victor A. Koelzer. Environmental Engineering was also developed by David W. Hendricks, Donald Dean Adrian, and Thomas G. Sanders.

During the same period, the Wind Engineering and Fluids Laboratory saw studies examining hazards associated with power plant pollution, siting of nuclear power stations, dispersion of dense gases due to chemical or liquified gas spills, flow in agricultural crops, bridge aerodynamics, pedestrian comfort around buildings, wind effects on space rocket launch facilities, snow drifting, 
odor pollution, wind turbine design and wind turbine facility siting, wind loads on solar collectors, etc. Currently the Wind Engineering and Fluids Laboratory is under the direction of Bogusz Bienkiewicz where he supervised the study of tornado dynamics in two new simulation facilities and evaluated wind effects on roofs and roof top pavers. The lab is managed by David E. Neff, who continues the tradition of basic and applied research focused on wind engineering problems.

The past decade or so has seen the renovation of the Engineering Building at a cost of approximately $\$ 18,000,000$. At the Civil Engineering Department the recent faculty positions were in the field of environmental hydraulics, environmental engineering, Endowed Chair in urban hydraulics, hydrology and hydraulics and water resources. There are currently about 35 FTE faculty positions in Civil Engineering and about 25 faculty members work in water and fluid mechanics.

\section{Summary And Conclusions}

With roots dating to 1870 and a foundation in 1957, the great success and rapid growth that CSU has experienced in a short period of time can be attributed to several factors. These certainly include: (1) commitment of faculty members who could build with vision; (2) endless energy and productivity of faculty, students and staff; (3) collaborative research with numerous governmental agencies, peer institutions, consulting firms, etc.; and (4) active involvement and visibility at the national and international level. In concluding, it can be said of CSU that its past was bright and the future...even better!

Acknowledgments As non-historians, the authors acknowledge delving into existing historical reports of the Institution. The authors of the following references deserve the credit for the historical research, while we assume the blame for any important omission in the preparation of this manuscript.

\section{References}

Albertson, M.L. and C.N. Papadakis (1986), "Megatrends in Hydraulic Engineering A commemorative Volume Honoring Hunter Rouse" Colorado State University, Department of Civil Engineering, 468p.

Anderson, (1970), "History of the Department of Civil Engineering", Unpublished report at CSU.

Anonymous..."The Practical Scholar - The Life of Elwood Mead", Unpublished Report.

Cermak, J.E. and M.L. Albertson, (1958), "Use of Wind Tunnels in the Study of Atmospheric Phenomenon," Air Pollution Control Association Annual Meeting, Paper No. 58-32, Philadelphia, PA, May 1958.

Hilfinger, A. (1989), "One hundred years of engineering at Colorado State University: Fulfilling the Land-grant Mission", College of Engineering, Colorado State University, 75p.

Rouse, H., (1976), "Hydraulics in the United States 1776-1976" Iowa Institute of Hydraulic Research, The University of Iowa, Iowa City, 238 p.

Rouse, H. (1980), "Hydraulics, Fluid Mechanics and Hydrology at Colorado State University", Engineering Research Center, Colorado State University, Fort Collins, Colorado, 87p. 